UDC 697.331:697.341

A. A. Malinovskyi, Dr. Sc. (Tech.), Prof., orcid.org/0000-0001-9765-3494,

V. H. Turkovskyi, Cand. Sc. (Tech.), Assoc. Prof., orcid.org/0000-0003-1869-8139,

A.Z. Muzychak, Cand. Sc. (Tech.),

orcid.org/0000-0002-6330-1076,

M. B. Sabat, Cand. Sc. (Tech.),

orcid.org/0000-0001-7448-0615
DOI: $10.29202 /$ nvngu/2018-1/19

State Higher Educational Institution Lviv Polytechnic National University, Lviv, Ukraine, e-mail: malinowski@polynet.lviv.ua; voltur@polynet.lviv.ua; mAndriy@polynet.lviv.ua; myroslav.b. sabat@lpnu.ua

\title{
GENERALIZED APPROACH TO MODES ANALYSIS OF MODERN HEAT SUPPLY SYSTEMS
}

\author{
А. А. Маліновський, д-р техн. наук, проф., \\ orcid.org/0000-0001-9765-3494, \\ В. Г. Турковський, канд. техн. наук, доц., \\ orcid.org/0000-0003-1869-8139, \\ А. 3. Музичак, канд. техн. наук, \\ orcid.org/0000-0002-6330-1076, \\ М. Б. Сабат, канд. техн. наук, \\ orcid.org/0000-0001-7448-0615
}

\begin{abstract}
Державний вищий навчальний заклад Національний університет „Львівська політехніка“, м. Львів, Україна, е-таil: malinowski@polynet.lviv.ua; voltur@polynet.lviv.ua; mAndriy@ polynet.lviv.ua; myroslav.b.sabat@lpnu.ua
\end{abstract}

\section{УЗАГАЛЬНЕНИЙ ПІДХІД ДО АНАЛІЗУ РЕЖИМІВ СУЧАСНИХ СИСТЕМ ТЕПЛОПОСТАЧАННЯ}

Purpose. Solving analysis problems and improvement of modern physically inhomogeneous heat supply and heating systems. Developing the mathematical models that are suitable for applying all the features of the theory of energy circuits.

Methodology. The study was conducted through applying fundamental laws of physics, fundamental principles of the theory of energy circuits and sectoral theories of hydraulic and electrical circuits, formalized methods for analysis of utility networks, methods of mathematical modeling.

Findings. Contour and nodal mathematical models were improved as an instrument of a generalized approach to the modes analysis of heat supply and heating systems. It has been shown that the mathematical models can adequately reproduce modes of studied systems. The models take into account the nature of the power and features of the two forms of mechanical energy - kinetic and potential. It is important for the analysis of mine heating modes, as there are considerable differences in height and emergency modes, due to leakages of heat-transfer agent to the environment.

Originality. The generalized approach complies with all the requirements by principles of the metrical and energy analogies. It allows applying previously unavailable tools for the modes analysis of heating systems, in particular, power balance. The important advantage of this approach is the observance of unified system variables, which allows describing the phenomenon in circuits of different physical nature.

Practical value. The developed mathematical models provide an effective tool for analysis of the planned and existing modern heat supply systems and their optimization in terms of minimizing energy costs.

Keywords: heat supply and heating, hydraulic circuit, metric and energy analogies, energy circuit, power balance

Introduction. Heat supply system is an important component of power supply for the coal mining. Thermal energy is needed for heating the air that is supplied to the mine for domestic usage and preventing mineshaft icing during the cold season.

Heat is provided by heat-technical installations (boilers), which usually operate on coal. According to [1] the amount of thermal energy needed for mining coal unit is the same as the amount of needed electricity and sometimes more. For the abovementioned purpose, coal is written off for simpler internal calculation or through offsets [2] so expenditures for heat supply in the mines are not paid enough attention.

(C) Malinovskyi A.A., Turkovskyi V. H., Muzychak A.Z., Sabat M. B., 2018
A significant energy consumption contributes to high cost of coal mining, which is one of the reasons for losses - the profitability of the majority of domestic mines is within 0.74 [3]. It must be noted that heating is ranked as the third the most costly part of coal mining technology [1].

Thus, the question of efficient heat energy consumption by the mine companies is very acute. The issue cannot be solved without providing energy efficient modes of heat supply system [4], in particular, under typical conditions for mining companies where a varying load and a fixed load are occurring within the same system.

The discussed problem can be solved only by applying the modern methods for analysis and improvement of heat supply system modes (including hydraulic modes) as a whole, taking into account all the components of such 
systems (source-network-heat unit-customer). This requires a system approach to the analysis of elements of different nature and structure with regard to the relationship between all elements of the system.

Unsolved aspects of the problem. The formalized methods for the hydraulic modes analysis of heat supply systems have been applied through the interdisciplinary theory of hydraulic circuits [5]. The abovementioned approach is based on the replacing of the heat supply system by hydraulic circuit. Contour sets of equations for the hydraulic circuit (contour mathematical model) in matrix-vector form looks like $[4,5]$

$$
\left\{\begin{array}{l}
A \vec{X}_{m}=-\vec{G}_{m} \\
B \vec{Y}=0 \\
\vec{Y}=\vec{E}-\Delta \vec{p}_{d}
\end{array},\right.
$$

where $A, B$ are incidence and circle matrixes; $\vec{X}_{m}$ is the column vector of the heat carrier mass flows and $\vec{Y}$ is the column vector for the pressure differentials of branches; $\vec{G}_{m}$ is column vector of the heat carrier mass flows in the nodes; $\vec{E}$ is the column vector of operating pressures in branches; $\Delta \vec{p}_{d}$ is the column vector of pressure losses (transformation of mechanical energy into thermal) in the branches of the hydraulic circuit.

For heat supply systems and heating systems vector operating pressures in the branches should be defined as

$$
\vec{E}=g \rho \vec{H},
$$

where $\vec{H}$ is the column vector of operating heads in branches; $\rho$ is the diagonal matrix of the heat carrier densities in the branches; $g$ is gravity of Earth.

The nodal mathematical model is different from the contour model due to the form of Kirchhoff's second rule [5].

The mathematical apparatus of the theory of hydraulic circuits is focused on the analysis of modes for homogeneous hydraulic systems. However, domestic heating systems had homogeneous hydraulic nature 20-30 years ago. Development of the modern heat supply systems is associated with significant complication of their construction as well as with wide implementation of automatic control equipment for hydraulic and thermal-hydraulic modes [6] (mixed pumps, pressure regulators, heat flow regulators, and others). Hence, the heat supply systems are increasingly becoming physically heterogeneous.

Solving the problem of analysis of modes for heat supply systems is impossible without consideration of its all elements, including those with the different physical nature.

Therefore, physically heterogeneous heat supply systems as well as consumers' heating systems require developing the new approaches to the modes analysis that will take into account the network essence of task.

Analysis of the recent research and publications. A concept of the energy circuit was introduced for generalized representation of properties of system components with different physical natures [7]. The concept aims to com- bine mathematical representation of the different physical processes and phenomena within one mathematical model.

An important role is performed by principles of analogy that are applicable for certain common properties, attributes or relations of different subjects and phenomena. The theory of the energy circuits is based on two principles: metric analogy and energy analogy [7].

The principle of metric analogy requires a selection of the key action variables (flow and effort) that are conformed to Kirchhoff's first or second rule [7].

The principle of energy analogy allows taking the fundamental physical law of the energy conservation as a basis of equation branch [7, 8]. One of the most important statements of the energy analogy principle is a requirement for the product of effort for flow to give power

$$
Y \cdot X=P
$$

where $X$ is a serial action variable or flow; $Y$ is a parallel action variable or effort, $P$ is branch power (energy flow) of the energy circuit.

Hence, the principle of continuous power generation and power consumption in the circuit is valid.

Two other statements of the energy analogy principle allow obtaining dependencies for defining the two energy forms: potential and kinetic [8]. These statements define the requirements for determining parallel and serial state variables (mass and impulse) of the circuit.

Compliance with the aforementioned statements of the metric and energy analogies makes it possible to apply common approaches to the analysis of all elements of heat supply systems and to realize the benefits of formalized methods for the analysis.

The theory of energy circuits is the basis of modern approach to improving energy systems modes, especially heat energy systems, improving their energy efficiency and form a coherent picture for perception of modern heat supply systems.

Unsolved aspects of the problem. The principles of formalization for phenomena in circuits of differential natures are known. However, many sectoral disciplines are applying the system variables that do not satisfy them. Such theories include, in particular, the theory of hydraulic circuits and the theory of thermal circuits.

As a result, neither the hydraulic circuits theory nor the thermal circuits theory can apply all the possibilities of mathematical tools available through the theory of energy circuits. For example, the power budget cannot be formed, as is the case with the theory of electrical circuits. It also complicates the analysis of system modes which include physically heterogamous elements.

Objectives of the article. This study aims to prove the possibility of using a generalized approach to the theory of energy circuits for solving the problems of modes analysis within heat supply systems. Therefore, the contour and nodal mathematical models of heat supply system and heating system need to be improved and meet all principles of metric analogy and energy analogy.

It is necessary to consider the efficiency of the proposed approach for solving the problems of analysis and 
improvement modes within heat supply systems with dependent connection of consumers to a heat network both via mixed valves and via heat entries with mixed pumps.

Presentation of the main research and explanation of scientific results. Featured mathematical tools of the theory of hydraulic circuits are considered in comparison with mathematical tools of the theory of electric circuits.

In the theory of electric circuits voltage $U[\mathrm{~V}]$ is accepted as a parallel action variable (force) (set of these variables is conformed to Kirchhoff's second rule). Current strength $I[\mathrm{~A}]$ is accepted as a serial action variable (flow) (set of these variables is conformed to Kirchhoff's first rule) [9].

Such basis pair of variables allows obtaining a complete picture of communication [8] between the major variables of an electric circuit (Fig. 1).

The basis of such connection is the compatibility of the dimensions for the main pair of variables for which their product yields a stream of energy or power (it is rounded by a dashed line in Fig. 1).

State variables that are the integral values of the action variables, such as the magnetic flux $\Phi[\mathrm{Wb}]$ and the electric charge $q[\mathrm{C}]$ complement this link. They form the basis of the definition of two forms of energy - kinetic energy $W_{k}$ and potential energy $W_{p}$.

The contour set of the state equations for electric circuit (contour mathematical model) corresponds to the contour set of the state equations for hydraulic circuit (1) and looks as

$$
\left\{\begin{array}{l}
A \vec{I}=-\vec{J} \\
B \vec{U}=0 \\
\vec{U}=\vec{E}-\Delta \vec{U}
\end{array},\right.
$$

where $\vec{I}, \vec{U}$ are the column vectors of currents and voltages of the branches; $\vec{J}$ is the column vector of the current sources in nodes; $\vec{E}$ is the column vector of electromotive forces in the branches of electric circuit, $\Delta \vec{U}$ is the column vector of voltage drops in the branches.

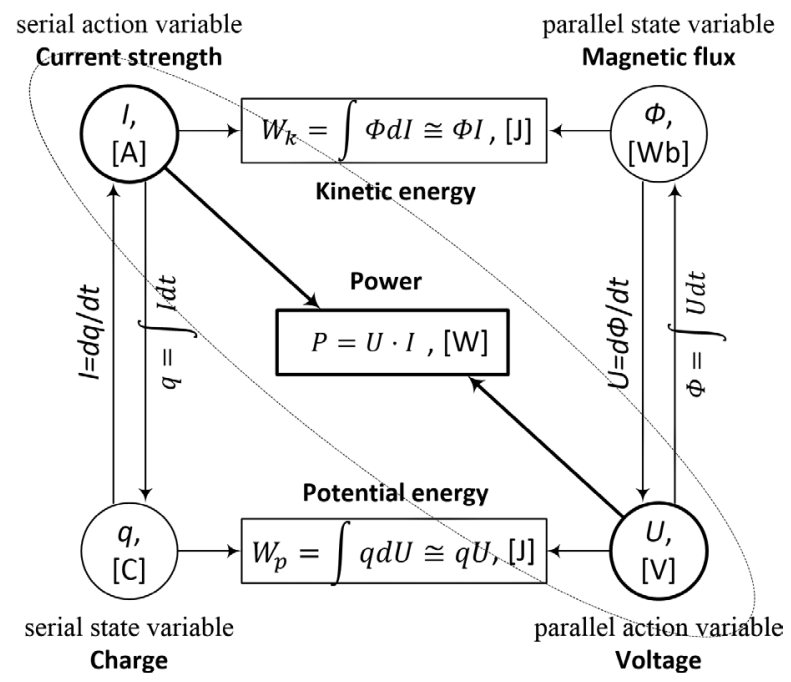

Fig. 1. Rectangle of bonds between the basic electric circuit variables
The result of solving the set of equations is the currents vector and voltages vector of electric circuit branches. As the product of these two variables gives power $P$ [W], making the power balance of electric circuit is easy.

According to the formal methods of analysis the formula for determining power of energy sources (regarding linear DC electric circuits for which the hydraulic circuits are appropriated) looks as [9]

$$
P_{s}=\vec{E} \vec{I}-\vec{U}_{n} \vec{J},
$$

and consumers' power

$$
P_{c}=\Delta \vec{U} \vec{I}=(R \vec{I}) \vec{I},
$$

where $R$ is matrix of the resistances branches of DC electric circuit; $\vec{U}_{n}$ is the column vector of the electric circuit nodal voltages. In equations $(2,3)$ the product of vectors is scalar.

In addition, the system variables can define the potential energy form (as the form of an electrostatic field capacitor) and kinetic energy form (as the form of magnetic field inductance) of the electric circuit (Fig. 1). Quantitatively, they can be defined as the integral of state variables for the corresponding action variables, and qualitatively this connection can be illustrated through their product.

According to the theory of hydraulic circuits pressures drop $\Delta P[\mathrm{~Pa}]$ (set of these variables is conformed to Kirchhoff's second rule) and heat carrier mass flow $X_{m}[\mathrm{~kg} / \mathrm{s}]$ (set of these variables is conformed to Kirchhoff's first rule) are assumed for the main pair of variables [5]. However, the variables pair does not fulfill the basic statement of energy analogy principle - the variables' product is not power

$$
\Delta P \cdot X_{m} \neq P,
$$

or in dimensions

$$
\begin{gathered}
{[P a] \cdot\left[\frac{\mathrm{kg}}{\mathrm{s}}\right]=\left[\frac{\mathrm{N}}{\mathrm{m}^{2}} \cdot \frac{\mathrm{kg}}{\mathrm{s}}\right]=\left[\frac{N \cdot \mathrm{m}}{\mathrm{m}^{3}} \cdot \frac{\mathrm{kg}}{\mathrm{s}}\right]=} \\
=\left[\frac{\mathrm{J}}{\mathrm{m}^{3}} \cdot \frac{\mathrm{kg}}{\mathrm{s}}\right]=\left[W \cdot \frac{\mathrm{kg}}{\mathrm{m}^{3}}\right] \neq[W],
\end{gathered}
$$

i.e. dimension of parallel and serial variables product does not correspond to the power unit.

The result leads to disrupted harmonious relationship between the main variables of the hydraulic circuit (Fig. 2), which is inherent for variables of the electric circuit (Fig. 1).

Connection between such state variables as mass $M[\mathrm{~kg}]$ and pressure impulse $I_{p}[\mathrm{~Pa} \cdot \mathrm{s}]$ and their corresponding action variables is also disrupted. In this case it is not possible to obtain the kinetic $W_{k}$ and potential $W_{p}$ forms of energy.

As a result, the equations of power balance such as (5) and (6) cannot be applied, that is unexpected to some extent. The continuity of power generation and power consumption is present in the hydraulic circuit as well as in the electric circuit. Moreover, there is no possibility to determine the potential and kinetic forms of energy (according to the principle of energy analogy). It leads to 
some incompleteness of the formalized methods in the theory of hydraulic circuits.

The possible solution of abovementioned drawbacks is selecting the following variables as a basic pair:

- volume flow of heat carrier $X_{v}\left[\mathrm{~m}^{3} / \mathrm{s}\right]$ is equivalent flow (serial action variable);

- pressures drop $\Delta P[\mathrm{~Pa}]$ is equivalent effort (parallel action variable).

The product of these basis variables gives power

$$
\Delta P \cdot X_{v}=P
$$

or in dimensions

$$
[P a] \cdot\left[\frac{m^{3}}{s}\right]=\left[\frac{N}{m^{2}} \cdot \frac{m^{3}}{s}\right]=\left[\frac{N \cdot m}{s}\right]=\left[\frac{J}{s}\right]=[W] .
$$

The selected pair of variables corresponds to the first statement of the principle of energy analogy. It is necessary to prove that this pair of variables is also subordinated to Kirchhoff's rules.

Pressures drop $\Delta P$ (effort) conforms with the eponymous variable of the theory of hydraulic circuit [5], so there is no need for separate proof, that this variable is subordinated to Kirchhoff's second rule.

With regard to the volume flows $X_{v}$ of the heat carrier there are some warnings. Proof that the set of mass flows $X_{m}$ is subordinated to Kirchhoff's first rule is derived from a fundamental law of nature - the law of mass conservation. Hence, equality of the volume flows can be disturbed.

Therefore, it is important to consider in detail the conditions under which the set of volume flows can subordinate to Kirchhoff's first law. It is shown as an example of a node with three branches (Fig. 3) and the result will expand to a node with $n$ branches.

Let us assume there occurs flow separation in a node (Fig. 3).

Over the time of $d t$ the liquid volume $d s_{1} v_{1} d t$ flows into through the area of the living section jet $d s_{1}$ in plane

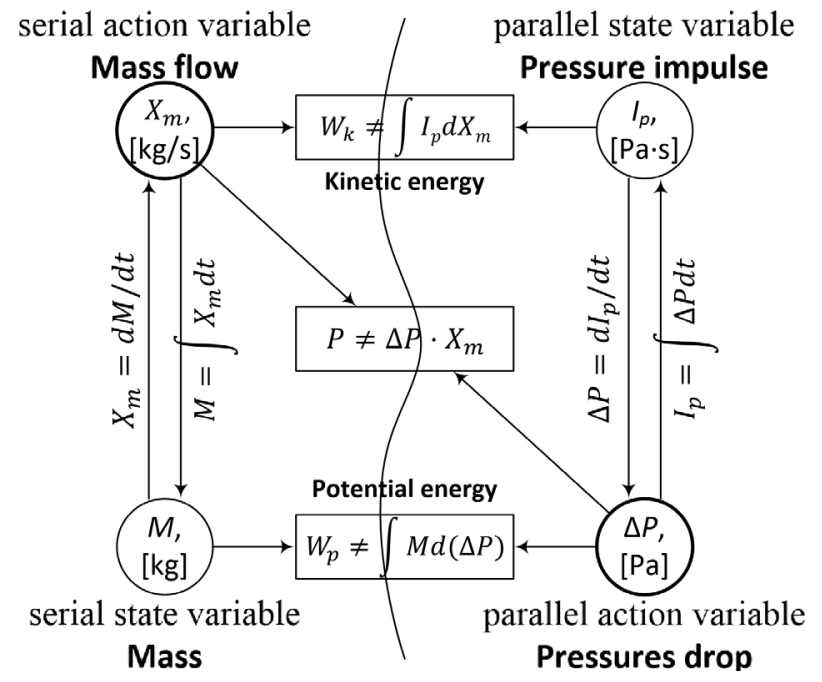

Fig. 2. Rectangle of bonds between the basic hydraulic circuit variables (as the basic pair variables are selected pressures drop $\triangle P$ and mass flow of heat carrier $X_{m}$ )
$1-1$. Over the same time of $d t$ the liquid volume $d s_{2} \mathrm{v}_{2} d t$ flows out through the hydraulic section $d s_{2}$ in plane $2-2$ and through plane $3-3$ the liquid volume $d s_{3} \mathrm{v}_{3} d t$ flows out. According to the continuity equation of flow provided that the fluid is incompressible (its density remains constant during movement), the liquid volume that flows in plane $1-1$ during time $d t$ is equal to the liquid volume that flows out in plains $2-2$ and $3-3$ over the same time.

A lot of liquids accord with this provision including water for which the change in pressure of 1 to $10 \mathrm{MPa}$ increases water density by about $0.5 \%$. Hence, the abovementioned principles are correct for water heat supply systems.

For the node (Fig. 3) equation $d s_{1} \mathrm{v}_{1} d t=d s_{2} \mathrm{v}_{2} d t+$ $+d s_{3} \mathrm{v}_{3} d t$ is obtained which can be reduced to the form

$$
-v_{1} d s_{1}+v_{2} d s_{2}+v_{3} d s_{3}=0
$$

that also corresponds to Kirchhoff's first rule (positive flow is taken from the node).

Similar equation can be taken for the three branches node with the merging flows (Fig. 4).

According to the continuity equation of flow, the liquid volume that flows in the planes $2-2$ and 3-3during time $d t$ is equal to the liquid volume that flows out in the plane $1-1$ over the same time. This can be written as

$$
v_{1} d s_{1}-v_{2} d s_{2}-v_{3} d s_{3}=0
$$

Following the equations $(4,5)$ a continuity equation can be written for a generalized node

$$
\mathrm{v}_{1} d s_{1}-\mathrm{v}_{2} d s_{2}-\mathrm{v}_{3} d s_{3}+\ldots+\mathrm{v}_{m} d s_{n}=0,
$$

where minus sign means, that flow is directed to the node.

After integrating the equation (6) within the respective flows, an equation equivalent to Kirchhoff's first rule can be obtained



Fig. 3. Three branches node with flow separation

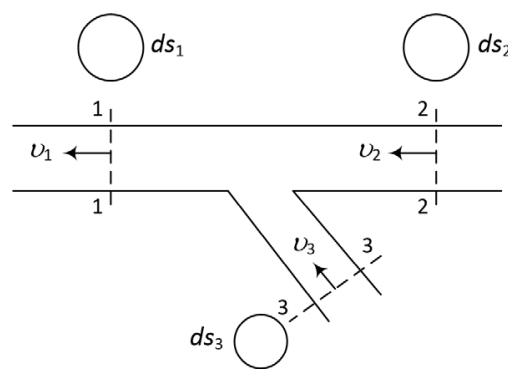

Fig. 4. Three branches node with the merging flows 


$$
X_{v 1}-X_{v 2}-X_{v 3}+\ldots+X_{v n}=0 .
$$

Thus, it can be argued that volume flows of heat carrier, which is selected as a serial variable (flow), is subordinated to Kirchhoff's first rule.

Hence, the selected pair of variables can be applied for problems analysis of engineering pipeline systems including heat supply systems. In this case, the relationship between the main variables of hydraulic circuit is similar as in Fig. 5.

Using of the pressure drop and the volume flow as a pair of basic variables and their corresponding state variables, allows calculating two forms of energy. Kinetic form of energy is proportional to the product $I_{p} X_{v}$, or in dimensions

$$
[P a \cdot s] \cdot\left[\frac{m^{3}}{s}\right]=\left[\frac{N \cdot s}{m^{2}} \cdot \frac{m^{3}}{s}\right]=[N \cdot m]=[J] .
$$

Potential form of energy is proportional to the product $V \Delta P$, or in dimensions

$$
\left[m^{3}\right] \cdot[P a]=\left[m^{3} \cdot \frac{N}{m^{2}}\right]=[N \cdot m]=[J] .
$$

Next, changes should be made to the system of the state equations for the hydraulic circuit (1).

After replacing the mass flow of heat carrier by the volume flow the first equation of system (1), which corresponds to Kirchhoff's first rule, needs to be changed. Thus, the contour mathematical model (contour set of state equations) of a heat supply system (1) takes the form

$$
\left\{\begin{array}{l}
A \vec{X}_{v}=-\vec{G}_{v} \\
B \vec{Y}=0 \\
\vec{Y}=\vec{E}-\Delta \vec{p}_{d}
\end{array},\right.
$$

serial action variable

Volume flow

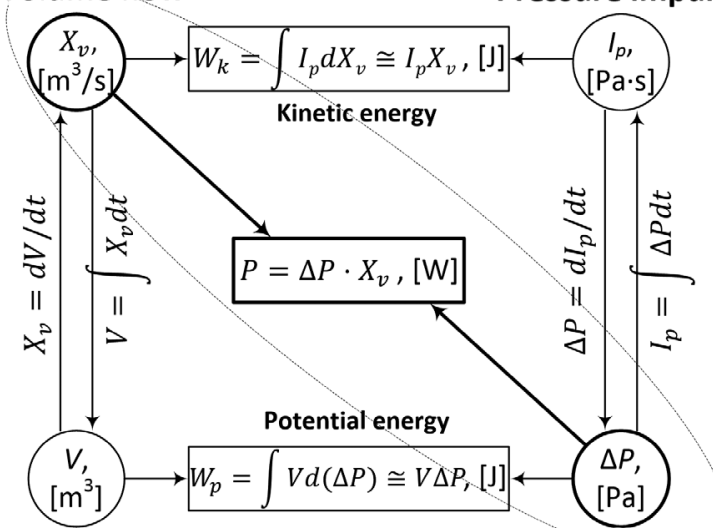

serial state variable Volume

parallel action variable Pressures drop

Fig. 5. Rectangle of bonds between the basic hydraulic circuit variables (pressure drop $\Delta P$ and volume flow of heat carrier $X_{v}$ are selected as the basic pair variables) where $\vec{X}_{v}$ is the column vector of heat carrier volume flows; $\vec{G}_{v}$ is the column vector of heat carrier volume flows in the nodes.

Linear equations (7) are complemented by nonlinear pole equation, which is an analytical form of pressureflow characteristics of system elements

$$
\Delta p_{m}=f\left(X_{v}\right) \text {. }
$$

Pressure-flow characteristics are to be approximated by power dependence on mass flow of the heat carrier, for example, quadratic function [5] or cubic polynomial [4]. With regard to volume flow of the heat carrier, cubic polynomial will look like

$$
\Delta \vec{p}_{m}\left(X_{v}\right)=\left(s_{1}\left|X_{v}\right|+s_{2}\left|X_{v}\right|^{2}+s_{3}\left|X_{v}\right|^{3}\right) \operatorname{sgn}\left(X_{v}\right)
$$

where $s_{1}, s_{2}, s_{3}$ are factors of approximation polynomial.

Comparison of function (8) and similar function given in [4] shows that the difference in (8) is absence of the specific volume of the heat carrier. It means that both functions have equal reproduction accuracy for pressure-flow characteristics of system elements (pipelines, circulation pumps, and others).

Let us show this by the example of a steel (steel electric-welded) pipeline with passage diameter $d_{y}=50 \mathrm{~mm}$ (inner diameter $d_{i n}=65 \mathrm{~mm}$ ) and length $100 \mathrm{~m}$. Approximation is traditionally performed by the weighted least squares method. The factors of the cubic approximation polynomial for both cases are shown in Table 1.

Approximation accuracy is estimated through the maximum relative error and the coefficient of variation. For both cases the maximum relative error is equal to $5.21 \%$ and the coefficient of variation is equal to $0.169 \%$.

The same is true for the pipelines with other diameters or produced from other materials.

It should be noted that water cinematic properties significantly depend on temperature. Thus, polynomial factors $(8)$ have different values for straight pipeline $\left(130^{\circ} \mathrm{C}\right)$ and return pipeline $\left(70^{\circ} \mathrm{C}\right)$ of the same diameter and material (Table 2).

It concerns both polynomial (8) and polynomial with mass flow [4].

Taking into account the pole equation in form (8) the contour mathematical model (7) of the heat supply system will take a form

Table 1

Calculated polynomial factors* for the volume (8) and the mass [4] flows of a heat carrier for a steel pipeline with $\mathrm{dp}=50 \mathrm{~mm}$ and length $100 \mathrm{~m}$

\begin{tabular}{|c|c|c|c|c|}
\hline $\begin{array}{c}\text { Polyno- } \\
\text { mial }\end{array}$ & $\begin{array}{c}d_{p} / d_{i n}, \\
\mathrm{~mm}\end{array}$ & \multicolumn{3}{|c|}{ Polynomial factors } \\
\cline { 3 - 5 } & & $\begin{array}{c}S_{1}, \\
\mathrm{~kg} /\left(\mathrm{m}^{4} \cdot \mathrm{s}\right)\end{array}$ & $\begin{array}{c}s_{2}, \\
\mathrm{~kg} / \mathrm{m}^{7}\end{array}$ & $\begin{array}{c}s_{3}, \\
\mathrm{~kg} \cdot \mathrm{s} / \mathrm{m}^{10}\end{array}$ \\
\hline$(15), X_{v}$ & $50 / 65$ & $1.114 \cdot 10^{6}$ & $3.086 \cdot 10^{9}$ & $2.063 \cdot 10^{10}$ \\
\cline { 4 - 6 } & & $1.114 \cdot 10^{6}$ & $3.086 \cdot 10^{6}$ & $2.063 \cdot 10^{4}$ \\
\hline by [4], $X_{m}$ & & &
\end{tabular}

* approximation of pressure-flow characteristics is done for the heat carrier temperature $0{ }^{\circ} \mathrm{C}$. 


$$
\left\{\begin{array}{l}
A \vec{X}_{v}=-\vec{G}_{v} \\
B \vec{Y}=0 \\
\vec{Y}=\vec{E}-\left(S_{1}\left|\vec{X}_{v}\right|+S_{2}\left|\vec{X}_{v}\right|^{2}+S_{3}\left|\vec{X}_{v}\right|^{3}\right) \operatorname{sgn}\left(\vec{X}_{v}\right)
\end{array},\right.
$$

where $S_{1}, S_{2}, S_{3}$ are matrixes with approximation polynomial factors (8) for all elements of heat supply system or heating system.

Taking into account the node form of Kirchhoff's second rule the nodal mathematical model looks as

$$
\left\{\begin{array}{l}
A \vec{X}_{v}=-\vec{G}_{v} \\
\vec{Y}=-A^{T} \vec{P} \\
\vec{Y}=\vec{E}-\left(S_{1}\left|\vec{X}_{v}\right|+S_{2}\left|\vec{X}_{v}\right|^{2}+S_{3}\left|\vec{X}_{v}\right|^{3}\right) \operatorname{sgn}\left(\vec{X}_{v}\right)
\end{array},\right.
$$

where $\vec{P}$ is the column vector of pressures in the nodes.

Thereafter, the sets of equations $(9,10)$ are applied for calculating modes of heat supply system. Calculation results of such system are taken as reference values and are given in [4].

Heat supply system contains one source $(a)$ and four consumers $(b, c, d, e)$. Its scheme is shown in Fig. 6 (numbers 1-8 mark the supply pipelines of heat network, numbers 1'-8' mark the return pipelines). Parameters of the flow and return pipelines are the same as in [4].

The consumers $c$ and $e$ are connected to the heat supply system via mixed valves. The consumers $b$ and $d$ are connected to the system via heat entry with the mixed pump. The same scheme of consumers' connections is in the last example [4]. The consumer connection scheme to the network is indicated in Fig. 1 near every consumer.

Table 2

Calculated polynomial factors (8) for the straight and return pipelines

\begin{tabular}{|c|c|c|c|c|}
\hline \multirow{2}{*}{$\begin{array}{c}\text { Tempe- } \\
\text { rature }\end{array}$} & $d_{p} / d_{i n}$, & \multicolumn{3}{|c|}{ Polynomial factors } \\
\cline { 3 - 5 } & $\mathrm{mm}$ & $\begin{array}{c}S_{1}, \\
\mathrm{~kg} /\left(\mathrm{m}^{4} \cdot \mathrm{s}\right)\end{array}$ & $\begin{array}{c}S_{2}, \\
\mathrm{~kg} / \mathrm{m}^{7}\end{array}$ & $\begin{array}{c}S_{3}, \\
\mathrm{~kg} \cdot \mathrm{s} / \mathrm{m}^{10}\end{array}$ \\
\hline $130{ }^{\circ} \mathrm{C}$ & $50 / 65$ & $1.041 \cdot 10^{6}$ & $2.884 \cdot 10^{9}$ & $1.928 \cdot 10^{10}$ \\
\cline { 4 - 5 } & & $1.089 \cdot 10^{6}$ & $3.017 \cdot 10^{6}$ & $2.017 \cdot 10^{4}$ \\
\hline
\end{tabular}

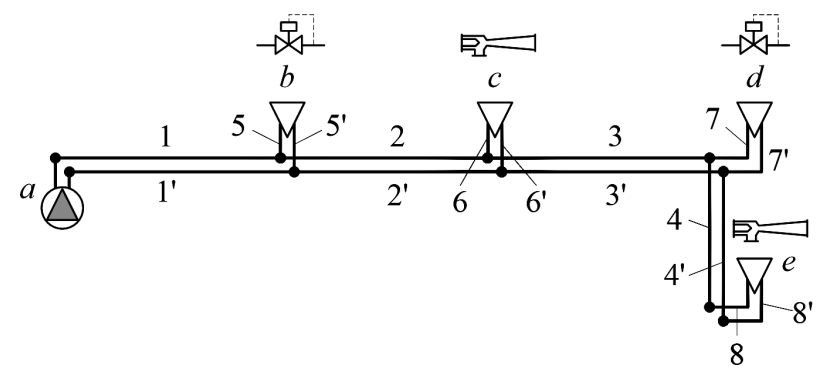

Fig. 6. Scheme of heat supply system with four consumers in two-line form
In the source $a$ the circulating pump NM 40/16-B with constant operating pressure $316.4 \mathrm{kPa}$ is installed.

All consumers are the same. According to [4] their heat load is equal to $0.324 \mathrm{Gcal} /$ hour and pressure loss in build network for design flow of heat carrier is equal to $18.22 \mathrm{kPa}$. Design volume flow of heat carrier in the build network is equal $3.685 \cdot 10^{-3} \mathrm{~m}^{3} / \mathrm{s}$ (corresponds to mass flow $3.577 \mathrm{~kg} / \mathrm{s}$ ).

According to temperature diagrams (in the heat network it is $130 / 70{ }^{\circ} \mathrm{C}$ and in the consumer network it is $95 / 70{ }^{\circ} \mathrm{C}$ ) mixture coefficient of mixing valve $u=1.4$ and volume flow removal of heat carrier from the straight pipeline is equal to $1.594 \cdot 10^{-3} \mathrm{~m}^{3} / \mathrm{s}$ (corresponds mass flow $1.49 \mathrm{~kg} / \mathrm{s}$ ).

In case of connecting consumers to the heat supply system via heat entry, the mixed pump NC4 65-30/340 is installed. The pump was selected following the condition of circulating of heat carrier in consumer network and mixing of heat carrier from the return pipeline. Its constant operating pressure is $25.99 \mathrm{kPa}$.

Graph of the heat supply system is shown in Fig. 7 (edge 0 corresponds to the source; edges $1-8,1^{\prime}-8^{\prime}$ correspond to the supply and return pipelines of the heat network in accordance; edges 9-20 correspond to equipment of heat entries and consumers).

The graph contains 8 chords, which correspond to 8 main contours. Numbering of contours is made in a special way. At first, there are contours that correspond to the chords which reproduce the equipment of the heat entry installed in the supply pipeline of the network (the nozzle of the mixed valve, the regulator of the heat flow, and others). These chords are 13,15, 17 and 18. Only after that the contours follow that correspond to the chords which reproduce the equipment of the heat network of consumers. These chords are 14, 16, 18 and 20.

The parameters of all system elements (elements of the matrixes $\mathbf{S}_{1}, \mathbf{S}_{2}, \mathbf{S}_{3}$ ) and operating efforts of the circulating pumps (elements of the vector $\vec{E}$ ) are needed to calculate the mode of the heat supply system. Values $s_{1}$, $s_{2}, s_{3}$ for the main equipment are shown in Table 3 .

First, it is necessary to determine the initial parameters of the consumers' input equipment. According to the methods [4] the nozzle diameter of the mixed valve should be determined by providing desirable coefficient of the mixing valve, so excessive pressure should be de-

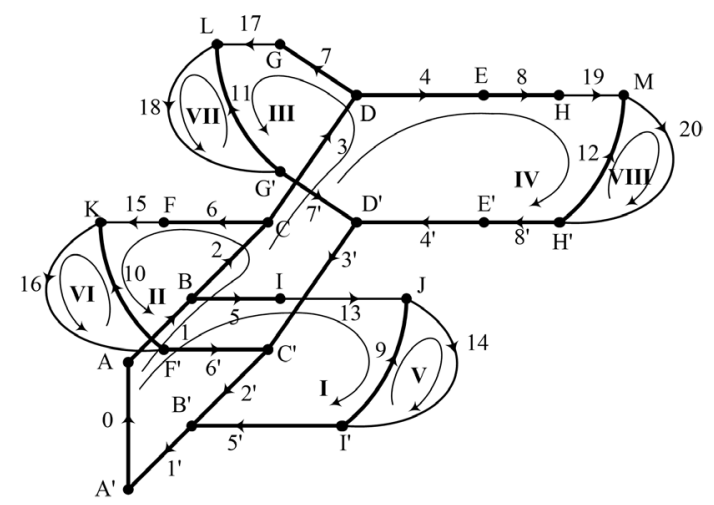

Fig. 7. Graph of the heat supply system which is shown in Fig. 5 with system of the main contours 
creased by a throttling orifice. The calculated parameters of the entry equipment are shown in Table 4.

The calculated modes parameters for the heat supply system and consumers according to the generalized approach and to [4] are shown in Table. 5.

From Table 5 it is clear that the deviations of the calculated flows of heat carrier from those given in [4] are insignificant. Thus, the proposed model adequately reproduces the modes of modern heat supply systems.

Moreover, the piezometric graph of heat network is built (Fig. 8). It corresponds to the graph that is given in [4].

According to the calculation results the power balance for hydraulic circuit is produced. All elements of the circuit are presented as nonlinear pressure-flow characteristics (8) so the formula of consumers' power (3) takes the form

$$
P_{c n}=\left[\left(S_{1}\left|\vec{X}_{v}\right|+S_{2}\left|\vec{X}_{v}\right|^{2}+S_{3}\left|\vec{X}_{v}\right|^{3}\right) \operatorname{sgn}\left(\vec{X}_{v}\right)\right] \vec{X}_{v},
$$

Table 3

Approximation function factors of pressure-flow characteristics for elements of the system

\begin{tabular}{|l|c|c|c|}
\hline \multirow{2}{*}{$\begin{array}{c}\text { Element of } \\
\text { the system }\end{array}$} & \multicolumn{3}{|c|}{ Polynomial factors $(10)$} \\
\cline { 2 - 4 } & $\begin{array}{c}s_{1}, \\
\mathrm{~kg} /\left(\mathrm{m}^{4} \cdot \mathrm{s}\right)\end{array}$ & $\begin{array}{c}s_{2}, \\
\mathrm{~kg} / \mathrm{m}^{7}\end{array}$ & $\begin{array}{c}s_{3}, \\
\mathrm{~kg} \cdot \mathrm{s} / \mathrm{m}^{10}\end{array}$ \\
\hline Consumer & $-4.23 \cdot 10^{4}$ & $1.36 \cdot 10^{9}$ & $-2.95 \cdot 10^{9}$ \\
\hline $\begin{array}{l}\text { Circulating pump } \\
\text { (NM 40/16-B) }\end{array}$ & $-1.82 \cdot 10^{5}$ & $-9.17 \cdot 10^{6}$ & $1.14 \cdot 10^{11}$ \\
\hline $\begin{array}{l}\text { Mixed } \\
\text { pump (NC4 } \\
\text { 65-30/340) }\end{array}$ & $1.34 \cdot 10^{6}$ & $2.34 \cdot 10^{8}$ & $-5.45 \cdot 10^{9}$ \\
\hline
\end{tabular}

$* d_{y}, d_{\text {in }}$ are the internal diameters of pipeline

Table 4

Calculated parameters of heat entries of consumers

\begin{tabular}{|c|c|c|c|c|}
\hline \multirow{2}{*}{ Parameter* } & \multicolumn{4}{|c|}{ Consumer of the system } \\
\cline { 2 - 5 } & $b$ & $c$ & $d$ & $e$ \\
\hline$d_{n} / d_{o}, \mathrm{~mm}$ & - & $11.3 /$ & - & $11.3 /$ \\
& & 11.9 & & 15.6 \\
\hline$\Delta p_{o}, \mathrm{kPa}$ & - & 83.8 & - & - \\
\hline$\Delta p_{r h}, \mathrm{kPa}$ & 235.2 & - & 150.9 & - \\
\hline
\end{tabular}

$* d_{n}, d_{0}$ are diameters of a mixed valve nozzle and diameter of a throttling orifice, accordingly; $\Delta p_{o}, \Delta p_{r h}$ are pressure losses in the throttling orifice and in regulator of the heat flow, accordingly

Table 5

Calculated parameters of mode and deviations from the parameters which are given in [4]

\begin{tabular}{|c|c|c|c|c|}
\hline \multirow{2}{*}{$\begin{array}{l}\text { Ele- } \\
\text { ment }\end{array}$} & \multicolumn{2}{|c|}{ Calculation data } & \multirow{2}{*}{$\begin{array}{c}\text { in [4] } \\
X_{m}, \mathrm{~kg} / \mathrm{s}\end{array}$} & \multirow{2}{*}{$\begin{array}{c}\delta X \\
\%\end{array}$} \\
\hline & $X_{v}, \mathrm{~m}^{3} / \mathrm{s}$ & $X_{m}, \mathrm{~kg} / \mathrm{s}$ & & \\
\hline$a$ & $6.362 \cdot 10^{-3}$ & 5.946 & 5.96 & -0.235 \\
\hline$b$ & $3.696 \cdot 10^{-3}$ & 3.58 & 3.577 & 0.075 \\
\hline$c$ & $3.669 \cdot 10^{-3}$ & 3.553 & 3.577 & -0.678 \\
\hline$d$ & $3.696 \cdot 10^{-3}$ & 3.58 & 3.577 & -0.074 \\
\hline$e$ & $3.668 \cdot 10^{-3}$ & 3.552 & 3.577 & -0.693 \\
\hline
\end{tabular}




\section{Table 7}

Calculated parameters of hydraulic and heat modes of consumers for deviation of heat carrier temperature by $10 \%$ relative to the normative one

\begin{tabular}{|c|c|c|c|c|}
\hline \multirow{2}{*}{$\begin{array}{c}\text { Con- } \\
\text { sumer }\end{array}$} & \multicolumn{2}{|c|}{ Calculated parameters } & \multirow{2}{*}{$\begin{array}{c}P_{\text {des }}, \\
\text { W }\end{array}$} & $\begin{array}{c}\delta P, \\
\%\end{array}$ \\
\cline { 2 - 3 } & $\begin{array}{c}X_{v}, \\
\mathrm{~m}^{3} / \mathrm{s}\end{array}$ & $\begin{array}{c}P, \\
\mathrm{~W}\end{array}$ & & \\
\hline$b$ & $3.723 \cdot 10^{-3}$ & 89.43 & 89.43 & 0.01 \\
\hline$c$ & $3.547 \cdot 10^{-3}$ & 69.83 & & -21.9 \\
\hline$d$ & $3.723 \cdot 10^{-3}$ & 89.43 & & 0.01 \\
\hline$e$ & $3.432 \cdot 10^{-3}$ & 67.57 & & -24.4 \\
\hline
\end{tabular}

$* P, P_{\text {des }}$ are calculated and desired heat power of consumer; $\delta P$, is deviation of the calculated heat power of the consumer from the desired

to provide the necessary heat power in network of consumers $b$ and $d$.

The results of calculation of the hydraulic and heat modes for consumers are shown in Table 7. The desired heat power and deviations from them are also shown in the table.

Data from Table 7 show that consumers $b$ and $d$ have desired heat mode. There is a deviation of the heat mode from the desired one for the consumers $c$ and $e$, in which there is no regulation on the thermal input.

The deviation of the heat mode in the network of the consumers from the desired exceeds the temperature deviation in the supply pipeline of the heat supply system. In the given example, the deviation of the heat mode for consumers $c$ and $e$ exceeds $20 \%$. The consumers, who are further along the main line from the source of heat energy, are particularly vulnerable to deviations of the temperature mode. The most deviation of heat mode in the heat supply system that is shown in Fig. 6 is for consumer $e$.

Deviation of temperature also causes the increase in power consumption. Total amount of power was increased and equals $2.401 \mathrm{~kW}$, which is $8.4 \%$ more than in the previous example. The hydraulic power of the circulation pump of the boiler will increase to $2.198 \mathrm{~kW}$ or more than $9.2 \%$.

Conclusions. From the standpoints of the generalized approach of the theory of energy circuits the contour and nodal mathematical models of heat supply and heating systems have been improved. As the main pair of variables volume flow of a heat carrier and pressure drop are selected, which corresponds to the principles of metric and energy analogies.

The effectiveness of the approach is proved by the example of a typical heat supply system where some consumers are connected via mixed valves and some consumers are connected via heat entries with mixed pumps.

The provisions that are given in the article are valid for water heat supply and heating systems.

\section{References.}

1. Boronin, V.F, Dotsenko, S.A. and Zhukov, Ju. P., 2014. Heat saving ways in the mines. Ugol' Ukrainy, 11, pp. 14-16.

2. Samusia, O.V., 2014. The methodology for calculating the costs per unit for thermal energy generation using heat-pine installations in coal mines. Scientific collected articles of national Mining University, 44, pp. 68-76. 3. Starychenko, L. L., 2012. Current issues of state policy concerning coal industry. Ugol' Ukrainy, 10, pp. 3-7. 4. Malinovskyi, A.A., Turkovskyi, V.H. and Muzychak, A.Z., 2014. Methodology of analysis and improvement of modes of district heating systems with direct connection of consumers. Naukovyi Visnyk Natsionalnoho Hirnychoho Universytetu, 1(139), pp. 85-91. 5. Mikhailovsky, E. M. and Novitsky, N. N., 2015. A modified nodal pressure method for calculating flow distribution in hydraulic circuits for the case of unconventional closing relations. St. Petersburg Polytechnical University Journal. Physics and Mathematics, 1(2), pp. 120-128. 6. Pyrkov, V. V., 2014. Energy efficiency of automatic balancing of new and modernized heat and hot water supply systems. Danfoss INFO, 1-2, pp. 12-17.

7. Sauh, S. E., 2011. Mathematical modeling of the power circuits. Electronic modelling, 33(3), pp. 3-12.

8. Muzychak, A., 2015. System of mode variables of energy circuits. Energy Engineering and Control Systems, 2, pp. 91-100.

9. Kyrylenko, O. V., Seheda, M.S., Butkevych, O. F. and Mazur, T.A., 2013. Mathematical modeling in electric power industry. Lviv: Vydavnytstvo Lvivskoi politekhniky.

Мета. Вирішення задач аналізу та удосконалення режимів сучасних фізично неоднорідних систем теплопостачання та опалення. Розроблення математичних моделей, придатних для застосування всіх можливостей теорії енергетичних кіл.

Методика. Для досягнення поставленої мети застосовувались фундаментальні фізичні закони, фундаментальні положення теорії енергетичних кіл і галузевих теорій гідравлічних й електричних кіл, формалізовані методи аналізу інженерних мереж, методи математичного моделювання.

Результати. Як інструмент узагальненого підходу до аналізу режимів систем теплопостачання та опалення вдосконалено контурну й вузлову математичні моделі. Показано, що ці математичні моделі дозволяють адекватно відтворити режими таких систем. У розроблених моделях ураховано мережний характер задачі та особливості двох форм механічної енергії - кінетичної й потенціальної. Це важливо в задачах аналізу режимів теплопостачання шахтного господарства, оскільки тут наявні значні перепади висоти, а також у задачах аналізу аварійних режимів, коли наявні витоки теплоносія до довкілля.

Наукова новизна. Запропонований узагальнений підхід відповідає всім вимогам принципів метричної та енергетичної аналогій теорії енергетичних кіл і дозволяє застосовувати для аналізу режимів систем теплопостачання раніше недоступні інструменти, наприклад, баланс потужності. Однією з важливих 
переваг Цього підходу є дотримання єдиної системи взаємозв'язаних змінних, що дозволяє описувати явища в колах різної фізичної природи.

Практична значимість. Запропоновані математичні моделі дають ефективний інструмент аналізу режимів проектованих і чинних сучасних систем теплопостачання та їх оптимізації з точки зору мінімуму енергетичних витрат.

Ключові слова: теплопостачання та опалення, гідравлічне коло, метричні та енергетичні аналогії, енергетичне коло, баланс потужності

Цель. Решение задач анализа и совершенствования режимов современных физически неоднородных систем теплоснабжения и отопления. Разработка математических моделей, пригодных для применения всех возможностей теории энергетических цепей.

Методика. Для достижения поставленной цели применялись фундаментальные физические законы, фундаментальные положения теории энергетических цепей и отраслевых теорий гидравлических и электрических цепей, формализованные методы анализа инженерных сетей, методы математического моделирования.

Результаты. Как инструмент обобщенного подхода к анализу режимов систем теплоснабжения и отопления усовершенствованы контурная и узловая математические модели. Показано, что эти математические модели позволяют адекватно воспроизве- сти режимы таких систем. В разработанных моделях учтены сетевой характер задачи и особенности двух форм механической энергии - кинетической и потенциальной. Это важно в задачах анализа режимов теплоснабжения шахтного хозяйства, поскольку здесь имеются значительные перепады высоты, а также в задачах анализа аварийных режимов, когда имеются утечки теплоносителя в окружающую среду.

Научная новизна. Предложенный обобщенный подход соответствует всем требованиям принципов метрической и энергетической аналогий теории энергетических цепей и позволяет применять для анализа режимов систем теплоснабжения ранее недоступные инструменты, например, баланс мощности. Одним из важных преимуществ этого подхода является соблюдение единой системы взаимосвязанных переменных, что позволяет описывать явления в цепях различной физической природы.

Практическая значимость. Предложенные математические модели дают эффективный инструмент анализа режимов проектируемых и действующих современных систем теплоснабжения и их оптимизации с точки зрения минимума энергетических затрат.

Ключевые слова: теплоснабжение и отопление, гидравлическая цепь, метрические и энергетические аналогии, энергетическая цепь, баланс мощности

Рекомендовано до публікації докт. техн. наук B.I. Дешком. Дата надходження рукопису 01.12.16. 